\title{
Persepsi Wisatawan Dengan Sapta Pesona Di Candi ljo Desa Sambirejo, Prambanan, Sleman
}

\author{
Wisnu Hadi ${ }^{1}$, Heni Widyaningsih ${ }^{2)}$ \\ Perhotelan, Fakultas Ekonomi Dan Bisnis ,Universitas Bina Sarana Informatika ${ }^{1)}$ \\ Jl. Ringroad Barat Ambarketawang, Gamping, Sleman, Yogyakarta \\ E-mail : wisnu.wsh@bsi.ac.id \\ Perhotelan, Akademi Pariwisata Yogyakarta2) \\ Jl. Baladewa,Babarsari, Glendongan, Tambak Bayan, Caturtunggal, Sleman Yogyakarta \\ Email : heni.widya08@akparyo.ac.id
}

\begin{abstract}
Abstrak
Program Sapta Pesona menjadi kewajiban sebagai pedoman dalam pengelolaan sebuah obyek wisata karena didalamnya ada unsur-unsur yang memberi hal-hal positif terhadap wisatawan yang berkunjung maka tujuan penelitian ini adalah mengetahui persepsi wisatawan terhadap Sapta Pesona di obyek wisata Candi ljo Prambanan Sleman. Untuk metode penelitian mengunakan deskriptif kualitatif, yaitu peneliti ingin mengetahui tentang aspek-aspek atau unsur-unsur pada program Sapta Pesona seperti keamanan, Kebersihan, ketertiban, keindahaan, kesejukkan serta keramahan dan kenangan sudah dilaksanakan dengan baik oleh pengelola wisata hal ini dari data yang didapat dari kueisoner dan wawancara kepada wisatawan yang pernah berkunjung ke obyek wisata Candi ljo Prambanan Sleman. Berdasarkan hasil penelitian persepsi wisatawan terhadap Sapta Pesona di obyek wisata Candi ljo di nilai sudah baik hal ini dari data pernyataan responden yang menyatakan bahwa unsur keamanan sudah berjalan baik, $88 \%$ responden menyatakan setuju, $12 \%$ menyatakan ragu-ragu. Ketertiban dalam saat menggunakan sarana dan prasarana Objek Wisata juga baik, 80\% responden menyatakan setuju, $12 \%$ ragu-ragu dan $8 \%$ tidak setuju. Kebersihan lingkungan obyek wisata juga dalam keadaan bersih, $80 \%$ responden menyatakan setuju, dan $20 \%$ ragu-ragu. Penataan tanaman yang indah membuat pengunjung merasa nyaman dengan kesejukan di dalam Objek Wisata, sebanyak $96 \%$ responden menyatakan setuju dan hanya $4 \%$ yang merasa ragu-ragu. Unsur keindahaan sudah sesuai dengan lingkungan sekitar obyek wisata ini ditata dengan teratur sehinga nyaman untuk di lihat pengunjung, 92\% responden setuju dan $8 \%$ ragu-ragu.. Dalam hal masalah keramah tamahaan 96 responden merasa mereka mendapatkan pelayanan yang sangat ramah baik dari masyarakat dan petugas sehingga tidak merasa cemas berada di objek wisata, dan $4 \%$ ragu ragu. Sedangkan untuk unsur kenangan $88 \%$ responden terkesan dengan keindahan alam di obyek wisata ini,, $8 \%$ ragu-ragu dan $4 \%$ tidak setuju.
\end{abstract}

Kata Kunci : Persepsi, Wisatawan, Sapta Pesona

\section{Perception Of Tourists With Sapta Pesona In The Ijo Temple Of Sambirejo Village, Prambanan, Sleman}

\begin{abstract}
The Sapta Pesona program is an obligation as a guideline in the management of a tourist attraction because in it there are elements that give positive things to visiting tourists. The aim of this study is that the researcher wants to know the perceptions of tourists about Sapta Pesona in ljo Prambanan Temple, Sleman. This study uses a qualitative descriptive method, namely the researcher wants to know that the elements in Sapta Pesona such as security, cleanliness, order, beauty, coolness and friendliness and memories have been carried out properly by the tour manager, this is from the data obtained from kueisoner and interviews with tourists who have been to the tourism object ljo Prambanan Sleman Temple. Based on the results of research on tourist perceptions of Sapta Pesona in the ljo Temple tourism object, the value is good, this is from the respondent's statement data which states that the security element has gone well, $88 \%$ of respondents agreed, $12 \%$ expressed doubt. Orderliness when using the facilities and infrastructure of the Tourism Object is also good, $80 \%$ of respondents agreed, $12 \%$ were in doubt and $8 \%$ disagreed. The cleanliness of the tourism object's environment is also in a
\end{abstract}


clean condition, $80 \%$ of respondents agree, and $20 \%$ are in doubt. The beautiful arrangement of plants makes visitors feel comfortable with the coolness in the tourism object, as many as $96 \%$ of respondents agree and only $4 \%$ feel doubtful. The element of beauty is in accordance with the environment around this tourist attraction arranged regularly so that it is comfortable to see by visitors, $92 \%$ of respondents agree and $8 \%$ are in doubt. In terms of hospitality issues 96 respondents feel they get very friendly service both from the community and officers so they don't feel anxious about being at a tourist attraction, and $4 \%$ are in doubt. As for the memory element, $88 \%$ of respondents were impressed by the natural beauty of this tourism object, $8 \%$ were in doubt and $4 \%$ disagreed.

Keyword: Perception, Tourists, Sapta Pesona

\section{PENDAHULUAN}

Industri pariwisata pada saat ini dalam kondisi yang sedang suram akibat Pandemi Covid-19 yang melanda seluruh dunia dan mempengaruhi segala aspek kehidupan yang ada di masyarakat tak terkecuali dengan obyek wisata yang aktivitasnya tidak lepas dengan wisatawan yang berkumpul dan berkerumun untuk menikmati keindahaan obyek wisata tersebut. Hal tersebut tentunya sangat akan dilarang disaat pandemic covid-19 karena resiko penularan sangat tinggi sehingga banyak obyek wisata melakukan penutupan sementara sambil menunggu pandemic Covid-19 mereda. Untuk itu pemerintah melakukan berbagai program untuk mengatasi penularan wabah tersebut dengan pengetatan serta pengawasan protocol kesehatan (prokes) saat obyek wisata dibuka nantinya untuk meminimalkan resiko penularan virus Covid-19.

Salah satu program yang telah berjalan dengan baik untuk aspek keamanan, kenyaman dan kepuasaan wisatawan adalah program Sapta Pesona dimana program berisi tentang perlindungan wisatwan yang berkunjung ke sebuah obyek wisata. Program ini masih sangat relevan dalam menghadapi masalah yang terjadi dalam pengelolaan suatu obyek wisata. Salah satu obyek wisata bersejarah di Provinsi Daerah Istimewa Yogyakarta yang terkenal adalah Candi ljo yang ada di kecamatan Prambanan Kabupaten Sleman.

Candi ljo ini merupakan bagian dari beberapa candi berada di kawasan candi di wilayah Kecamatan Prambanan Kabupaten Sleman. Candi ljo memiliki daya tarik karena terletak didaerah yang paling tinggi secara geografis diantara candi-candi lain. Pemandangan alam yang sangat menarik di Candi ljo karena wisatawan dapat melihat matahari terbenam (sunset). Selain itu, di Candi ljo wisatawan dari jauh dapat melihat pergerakkan pesawat di Bandara Internasional Adi Sutjipto Yogyakarta. Alasan utama wisatawan mengunjungi suatu lokasi wisata adalah karena daya tariknya. Persepsi wisatawan terhadap aspek keamanan, aspek ketertiban, aspek kebersihan, aspek kesejukan, aspek keindahan, aspek keramahan dan aspek kenangan tentu membuat wisatawan tertarik untuk melakukan kegiatan wisata di Candi ljo. Akses Candi ljo yang berada pada ketinggian memberikan daya tarik tersendiri, tetapi juga memberikan rasa takut akan aspek keamanan dalam menuju akses jalan menuju obyek wisata Candi ljo tersebut. Sehingga unsur sapta pesona juga harus diperhatikan dalam pengelolaan suatu lokasi wisata karena akan berpengaruh terhadap kepuasan wisata saat berwisata (Rajesh, 2013). Untuk itu penulis disini tertarik meneliti tentang Persepsi Wisatawan Dengan Sapta Pesona Di Candi ljo Desa Sambirejo, Prambanan, Sleman

\section{KAJIAN PUSTAKA}

\section{Persepsi}

Persepsi dari masing- masing individu pasti berbeda-beda. Perbedaan itu mengenai apa yang dipikirkan, dilihat, dan dirasakan. Hal itu berarti bahwa persepsi menggerakkan seseorang terhadap apa yang akan diperbuat untuk memenuhi berbagai keinginan baik untuk diri sendiri, keluarga, maupun lingkungan masyarakat sekitarnya. Menurut Ramadhani (2015) persepsi pada dasarnya cenderung bersifat psikologis bukan sekedar hanya merupakan proses penginderaan saja, maka terdapat faktor-faktor yang mempengaruhi nya, seperti perhatian yang selektif, individu lebih memperhatikan rangsang-rangsang tertentu saja, kemudian nilai dan kebutuhan dari masing- masing individu, dan yang terakhir adalah pengalaman dahulu. Pengalaman terdahulu sangat mempengaruhi oleh bagaimana seseorang memberikan persepsi tentang dunianya (Shaleh, 2009).

Ada berbagai faktor yang dapat mempengaruhi persepsi seseorang, factor 
tersebut adalah faktor internal dan faktor eksternal: (1) Faktor internal, faktor internal merupakan factor yang timbul dari dalam diri seseorang untuk menciptakan dan menemukan sesuatu yang kemudian dapat memberikan manfaat untuk orang bayak. Faktor internal yang dapat mempengaruhi persepsi, yaitu Usia, pendidikan, dan pekerjaan a) Usia, usia adalah tingkat umur individu yaitu dihitung mulai saat dilahirkan sampai ulang tahun. Semakin cukup umur seseorang, seseorang akan lebih matang dalam berpikir dan bekerja. Semakin tua umur seseorang semakin konstruktif dalam menggunakan pengetahuan yang diperoleh (Nursalam, 2011). Usia dapat mempengaruhi tingkat pengetahuan dan pengalaman seseorang, bilamana umurnya cukup, seseorang akan lebih matang dalam berpikir dan bekerja, b) Pendidikan, menurut Notoatmodjo (2012) orang yang mempunyai tingkat pendidikan tinggi akan memiliki taraf berfikir yang lebih rasional dibandingkan dengan orang yang berpendidikan rendah atau tidak berpendidikan sama sekali, c) Pekerjaan, pekerjaan merupakan sesuatu yang dilakukan untuk mencari nafkah. Masyarakat yang memiliki tingkat kesibukan yang tinggi akan memiliki sedikit waktu untuk memperoleh informasi. Dengan memilliki pekerjaan, seseorang dapat berbuat sesuatu yang bernilai, bermanfaat, memperoleh pengetahuan yang baik tentang pengetahuan sehingga lebih mengerti dan dapat memberikan persepsi yang positif terhadap sesuatu (Notoatmodjo, 2012). (2) Faktor eksternal, faktor eksternal merupakan faktor kebalikan dari faktor internal, yaitu faktor yang berasal bukan dari diri seseorang untuk menciptakan dan menemukan sesuatu. Faktor eksternal yang dapat mempengaruhi persepsi, yaitu informasi dan pengalaman, a).Informasi, Semakin banyak informasi yang diperoleh dapat mempengaruhi atau menambah pengetahuan seseorang, dengan memiliki pengetahuan seseorang akan memiliki kesadaran yang akan mempengaruhi perilaku sesuai dengan pengetahuan yang dimiliki (Notoatmodjo, 2012). b). Pengalaman, Menurut Azwar (2013), pengalaman adalah peristiwa atau kejadian yang pernah dialami seseorang. Sikap seseorang akan lebih mudah terbentuk apabila pengalaman pribadi tersebut terjadi dalam situasi yang emosi, sehingga akan terkenang lebih dalam.

\section{Obyek Wisata dan Wisatawan}

Kegiatan pariwisata tidak lepas dari kata wisata dan wisatawan yang saling berkaitan dalam aktivitas kepariwisataan baik secara nasional maupun internasional. Objek dan daya tarik wisata menurut undang-undang Nomor 9 Tahun 1990, yaitu Objek dan daya tarik wisata terdiri atas (1) Objek dan daya tarik wisata ciptaan Tuhan Yang Maha Esa, yang berwujud keadaan alam, dan juga flora dan fauna, (2) Objek dan daya tarik wisata hasil karya manusia seperti museum, peninggalan purbakala, peninggalan sejarah, seni budaya, wisata agro, wisata tirta, wisata buru, wisata petualangan alam, taman rekreasi, dan tempat hiburan

Wisatawan diartikan sebagai orang yang bepergian dari tempat tinggalnya untuk berkunjung ke tempat lain dengan menikmati perjalanan dan kunjungan itu. Sedangkan pendapat Fandeli (2001) bahwa wisatawan adalah seseorang yang melakukan perjalanan dan persinggahan sementara diluar tempat tinggalnya untuk jangka waktu lebih dari 24 jam dengan maksud untuk tidak mencari nafkah.

\section{Sapta Pesona}

Sapta Pesona, adalah konsep Sadar Wisata yang terkait dengan dukungan dan peran masyarakat sebagai tuan rumah dalam upaya untuk menciptakan lingkungan dan suasana kondusif yang mampu mendorong tumbuh dan berkembangnya industri pariwisata, melalui perwujudan unsur aman, tertib, bersih, sejuk, indah, ramah dan unsur kenangan. Unsur Sapta Pesona tersebut adalah aman, tertib, bersih, sejuk, indah, ramah, dan kenangan. 7 unsur pesona harus diwujudkan bagi terciptanya lingkungan yang kondusif dan ideal bagi berkembangnya kegiatan kepariwisataan di suatu tempat yang mendorong tumbuhnya minat wisatawan untuk berkunjung.

\section{Unsur Sapta Pesona}

Menurut Atmoko (2014) Bentuk aksi yang perlu diwujudkan dari masing-masing unsur Sapta Pesona tersebut yaitu (1) Aman, yaitu suatu kondisi sekitar di objek wisata atau daerah tujuan wisata yang dapat memberikan rasa tenang kepada wisatawan, tidak ada rasa takut dan rasa cemas oleh wisatawan yang melakukan perjalanan wisata tersebut, (2) Tertib, Suatu kondisi lingkungan dan pelayanan di daerah tujuan wisata yang mencerminkan sikap disiplin yang tinggi serta kualitas fisik 
serta pelayanan yang konsisten dan teratur yang diberikan oleh petugas secara efisien sehingga memberikan rasa nyaman bagi wisatawan, (3) Bersih, merupakan keadaan lingkungan yang disertai dengan kualitas produk dan pelayanan yang menunjukkan keadaan yang sehat/ higienis sehingga memberikan rasa nyaman dan senang bagi wisatawan dalam melakukan perjalanan atau kunjungan ke daerah tersebut, (4) Sejuk, Suatu keadaan lingkungan di destinasi wisata atau daerah tujuan wisata yang dapat memberikan suasana sejuk dan teduh sehingga akan memberikan perasaan nyaman dan "betah" bagi wisatawan dalam melakukan perjalanan atau kunjungan ke daerah tersebut, (5) Indah, suatu keadaan lingkungan di destinasi wisata atau daerah tujuan wisata yang menunjukkan lingkungan yang indah dan menarik sehingga wisatawan akan merasa kagum dan memberikan kesan yang mendalam bagi wisatawan sehingga ada potensi kunjungan ulang serta mendorong promosi ke pasar wisatawan yang lebih luas, (6) Ramah, suatu keadaan lingkungan yang berasal dari sikap masyarakat di destinasi wisata atau daerah tujuan wisata yang menunjukkan suasana yang akrab, terbuka, perasaan diterima dan wisatawan merasa betah dan menganggap seperti di rumah sendiri. (7) Kenangan, suatu perasaan yang berkesan sehingga menjadi pengalaman yang menyenangkan telah berkunjung tempat wisata tersebut. Terwujudnya unsur-unsur dalam Sapta Pesona pariwisata untuk pengembangan kepariwisataan di daerah akan memberikan dampak positif pada (1) meningkatnya tingkat kunjungan wisatawan ke objek wisata, (2) menjadi prospek usaha di bidang pariwisata, (3) meningkatkan pendapatan masyarakat karena dapat menciptakan lapangan pekerjaan bagi masyarakat sekitar.

\section{METODE PENELITIAN}

Penelitian ini dilakukan dengan metode deskriptif kualitatif, yaitu dengan menghasilkan data-data deskriptif berupa data-data baik secara tertulis maupun secara lisan dari obyek penelitian yang diamati (Satria,2010). Menurut Moleong, penelitian kualitatif adalah metode penelitian yang dilakukan untuk mengetahui dan memahami gejala fenomena ataupun kejadian yang dirasakan oleh penelitian, misalnya berkaitan dengan perilaku, persepsi, motivasi, tindakan, secara holistik dan dengan cara mendeskripsikan hasil temuan secara khusus dalam uraian yang dipaparkan dan dijelaskan secara alamiah dengan memanfaatkan berbagai metode ilmiah (Moleong, 2010), pengumpulan data dalam penelitian ini dilakukan dengan wawancara untuk menggali data dari wisatawan, observasi dengan mengamati kegiatan yang dilakukan oleh wisatawan serta studi pustaka berupa pendapat dari berbagai ahli untuk mendukung penelitian ini.

\section{HASIL DAN PEMBAHASAN}

Obyek wisata Candi ljo berada di Dukuh Groyokan, Desa Sambirejo, Kecamatan Prambanan, Kabupaten Sleman, Yogyakarta. Secara geografis Candi ijo merupakan candi yang letaknya paling tinggi di wilayah Yogyakarta. Keberadan Candi ljo dibangun antara abad ke 10 sampai 11 di sebuah bukit yang dikenal dengan sebutan bukit hijau yang mempunyai ketinggiannya sekitar $410 \mathrm{~m}$ di atas permukaan laut. Lokasi Candi ljo ini yang berada diketinggiam wisawatan bisa menikmati keindahan alam yang ada dibawahnya berupa teras teras mirip seperti daerah pertanian dengan kemiringan yang curam. Pada kompleks candi ini terdiri dari 17 struktur bangunan yang terbagi dalam 11 teras berundak. Saat masuk teras pertama sekaligus halaman menuju pintu masuk merupakan teras berundak yang membujur dari barat ke timur. Kemudian bangunan pada teras ke-11 terdiri pagar keliling, delapan buah lingga patok, empat bangunan yaitu candi utama, dan tiga candi perwara. Untuk peletakan bangunan pada tiap teras didasarkan atas kesakralannya. Adapun bangunan pada teras tertinggi adalah yang paling sakral.

Sebagai bangunan bersejarah Candi ljo akan dijumpai ragam bentuk seni rupa yang sudah terlihat mulai saat wisatawan melewati pintu masuk lokasi candi. Menurut ahli arkelog bahwa Candi ljo merupakan bangunan yang tergolong sebagai candi Hindu. Kemudian tepat di atas pintu masuk terdapat sebuah kala makara dengan motif kepala ganda dan beberapa atributnya. Motif kepala ganda dan atributnya ini dapat kita jumpai pada candi Buddha jadi candi ljo adalah bangunan candi sebagai bentuk akulturasi kebudayaan Hindu dan Buddha.Sebagai bangunan bersejarah Candi ljo mempunyai beberapa arca didalamnya ada arca yang menggambarkan sebagai sosok perempuan serta sosok laki-laki 
yang melayang dan mengarah ke sisi tertentu. Menurutnya sosok tersebut mempunyai beberapa makna. Pertama, sebagai suwuk untuk mengusir roh jahat dan kedua sebagai lambang persatuan antara Dewa Siwa dan Dewi Uma. Sehingga lambing persatuan tersebut dimaknai sebagai awal terciptanya alam semesta.

\section{Data responden}

Untuk itu dalam penyebaran kueisoner secara online ini peneliti mendapatkan 25 responden wisatawan yang pernah berkunjung di Candi ljo tersebut.

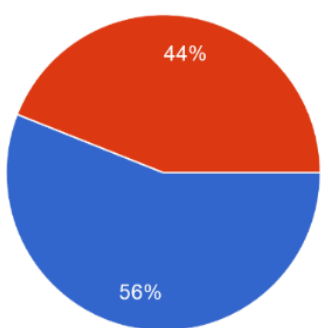

Laki-laki

Perempuan

Sumber Data Peneliti (2020)

Gambar 1. Grafik Tentang Jenis Kelamin Responden

Adapun profile yang diperoleh dari penyebaran kuesioner tersebut antara lain $56 \%$ adalah responden berjenis kelamin pria dan $44 \%$ berjenis kelamin wanita. Untuk usia para responden dalam penelitian ini didapat 36\% berusia $35-45$ Tahun dan $20 \%$ berusia $26-34$ Tahun dilanjut $16 \%$ berusia $15-25$ Tahun kemudian $12 \%$ adalah usia $<15$ Tahun dan usia 46 -54 Tahun. Dengan melihat usia tersebut ternyata pengunjung wisata di Candi ljo usia muda dan produktif

Tabel 1. Data Asal Daerah Responden

\begin{tabular}{clcc}
\hline No. & \multicolumn{1}{c}{ Keterangan } & Frek & Persentase \\
\hline 1. & Kabupaten Sleman & 10 & $40 \%$ \\
\hline 2. & Kabupaten Bantul & 5 & $20 \%$ \\
\hline 3. & $\begin{array}{l}\text { Kabupaten Kulon } \\
\text { Progo }\end{array}$ & 0 & $0 \%$ \\
\hline 4. & $\begin{array}{l}\text { Kabupaten Gunung } \\
\text { Kidul }\end{array}$ & 0 & $0 \%$ \\
\hline 5. & Kota Yogyakarta & 3 & $12 \%$ \\
\hline 6. & Luar Propinsi DIY & 7 & $28 \%$ \\
\hline$\quad$ Total & 25 & $100 \%$ \\
\hline
\end{tabular}

Sumber Data Peneliti (2020)

Data untuk domisili pengunjung Candi ljo

Sambirejo Prambanan Sleman adalah 40\% berasal dari Kabupaten Sleman wajar saja karena obyek wisata ini ada di wilayah tersebut dekat dengan Candi Prambanan dan Candi Boko yang termasuk wilayah Sleman. Kemudian $28 \%$ pengunjung berasal dari luar
Propinsi Yogyakarta serta $20 \%$ berasal dari Kabupaten Bantul dan 12\% berasal dari kota Yogyakarta.

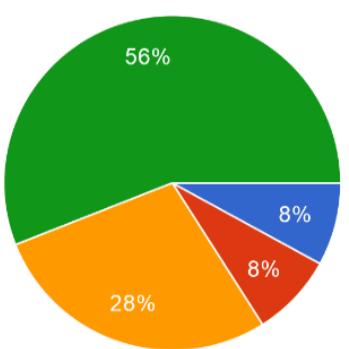

a. SD

b. SMP

c. SMA

d. PT (Diploma/S1/S2)

e. Lainnya

Sumber Data Peneliti (2020)

Gambar 2. Grafik Tentang Pendidikan Responden

Profile pengunjung dilihat dari segi pendidikan maka didominasi berpendidikan Perguruan Tinggi baik sudah lulus maupun masih kuliah yaitu 56\% kemudian yang berpendidikan SMA/SMK sebanyak $28 \%$ dan $8 \%$ berpendidikan SD dan SMP. Dengan data tersebut ternyata pengunjung wisata masih diminati anak muda dan mereka ingin mengetahui tentang sejarah sebuah candi yaitu Candi ljo. Selain itu pengunjung wisata Candi ljo merupakan wisatawan terdidik karena sambil berwisata mereka ingin belajar tentang sejarah candi.

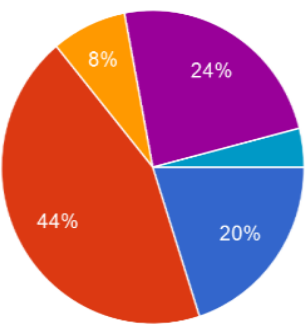

$$
\begin{aligned}
& \text { a. Wiraswasta } \\
& \text { b. Swasta/Karyawan } \\
& \text { c. PNS/TNI/POLRI } \\
& \text { d. BUMN } \\
& \text { e. Pelajar/mahasiswa } \\
& \text { f. Lainnya }
\end{aligned}
$$

\section{Sumber Data Peneliti (2020)}

Gambar 3. Grafik Tentang Latar Belakang Profesi Responden

Hal yang penting adalah data responden penelitian ini untuk pernyataan latar belakang profesi pekerjaan bahwa $44 \%$ adalah karyawan swasta kemudian $24 \%$ berlatarbelakang pelajar serta $8 \%$ berstatus PNS/TNI/POLRI serta hanya $4 \%$ berprofesi lain-lain. Dengan demikian wisatawan di Candi ljo banyak didominasi anak muda yang mahasiswa atau pelajar dan karyawan swasta menandakan wisatawan ingin sangat diminati untuk belajar sejarah candi sekaligus wisata keluarga swasta.

\section{Persepsi Wisatawan Tentang Sapta Pesona Di Obyek Wisata Candi ljo}

Peneliti sengaja melakukan penelitian untuk membahas gambaran persepsi 
wisatawan saat berkunjung disana tentang unsur-unsur di Sapta Pesona seperti unsur keamanan, ketertiban, kebersihan, kenyaman, keramahan dan kenangan sudah di nilai baik atau belum. Menurut 25 responden sebagai wisatawan yang pernah berkunjung ke obyek wisata Candi ljo memberikan penilaiaan tentang unsur-unsur tentang Sapta Pesona sebagai berikut :

\section{Unsur Aman}

Masalah dalam pengelolaan obyek wisata adalah aspek keamanan karena itu yang diharapkan oleh wisatawan untuk itu unsur aman menurut pendapat responden dalam mengisi kuesioner tersebut bahwa 88\% pengunjung menyatakan bahwa terdapat pos pengamanan yang siap siaga memantau rutinitas wisatawan dilokasi wisata. Sedangkan hanya $12 \%$ menyatakan masih ragu-ragu tentang hal tersebut karena responden selama pandemi Covid-19 belum berkunjung lagi ke Candi ljo sehingga tidak mengetahui perkembangannya saat ini.

Selain itu ada pernyataan responden tentang merasa aman dari ancaman kejahatan, seperti kecopetan, pemerasan dan penipuan di obyek wisata ini $88 \%$ sudah menyatakan sudah aman dan ancaman bahaya tersebut dan hanya $12 \%$ yang menyatakan menyatakan masih ragu-ragu. Tentang fasilitas parkir $84 \%$ responden merasa aman dalam memprakirkan kendaraannya dan hanya $12 \%$ menyatakan tidak tentang hal tersebut.

Hal yang lain adalah tentang fasilitas penerangan atau lampu di obyek wisata ini pengunjung $64 \%$ menyatakan cukup baik dan $12 \%$ menyatakan belum cukup baik serta $24 \%$ menyatakan ragu-ragu tentang hal tersebut karena Sebagian pengunjung melakukan kegiatan wisata pada siang hari sehingga kurang mengetahui keadaan pada malam hari. Kemudian penerangan jalan atau lampu sepanjang jalan menuju obyek wisata Candi ljo responden menyatakan $72 \%$ menyatakan sudah baik dan $28 \%$ menyatakan masih raguragu. Pengunjung yang menyatakan ragu ragu merasa sudah lama tidak mengunjungi Candi ljo sehingga lupa dengan kondisi penerangan di jalan menuju Candi ljo. Hal yang lain tentang fasilitas lampu juga masalah terhadap rambu-rambu dan pengaman di sepanjang jalan menuju obyek wisata ini pengunjung $80 \%$ menyatakan cukup baik dan $4 \%$ menyatakan belum cukup baik serta $16 \%$ menyatakan ragu- ragu tentang hal tersebut. Wisatawan yang menyatakan bahwa fasilitas lampu dan pengamanan jalan belum cukup baik dan wisatawan menyatakan ragu-ragu karena wisatawan tidak memperhatikan ada atau tidaknya lampu dan pengamanan di sepanjang jalan menuju Candi ljo.

\section{Unsur Tertib}

Unsur atau aspek selain aman adalah unsur tertib yang merupakan bagian aspek Sapta Pesona dimana untuk tanggapan pengunjung terhadap area parkir di Objek wisata telah teratur dan tertib hal ini dikatakan oleh $80 \%$ pengunjung wisatawan saat datang ke obyek wisata tersebut dan hanya $8 \%$ yang mengatakan tidak, selain itu hanya $12 \%$ yang masih mengatakan ragu-ragu tentang hal tersebut. Wisatawan yang menyatakan tidak tertib dan ragu ragu karena pedagang di area parkir masih belum tertata dengan tertib dan rapi.

Penggunaan sarana prasarana di obyek wisata ini menurut $68 \%$ responden mengatakan sudah tertib dan $32 \%$ yang mengatakan raguragu karena selama pandemi Covid-19 belum melakukan wisata ke Candi ljo lagi. Dalam masalah petugas dalam menangani kebersihan dan keamanan $88 \%$ menyatakan sudah tertib dan $12 \%$ masih ragu-ragu karena masih melihat ada yang membuang sampah sembarangan. Aspek dalam ketertiban yang lain bahwa terhadap respon informasi yang cejno pat dan akurat kepada pengunjung bahwa $84 \%$ mengatakan sudah baik serta $4 \%$ mengatakan tidak baik dan $12 \%$ menyatakan masih raguragu karena masih kesulitan mendapatkan informasi.

\section{Unsur Bersih}

Tanggapan pengunjung wisatawan Candi ljo untuk hal kebersihan $80 \%$ merasa nyaman terhadap lingkungan yang bebas dari sampah,dan kotoran lainnya dan 20\% menyatakan ragu-ragu terhadap hal tersebut karena masih ada debu di lingkungan candi.

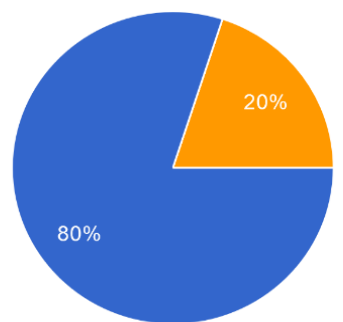

Sumber Data Peneliti (2020) 
Gambar 4. Grafik Tentang Unsur Kebersihan Lingkungan Di Obyek Wisata

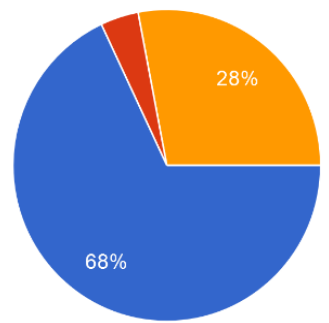

Ya Tidak Ragu-ragu

Sumber Data Peneliti (2020)

Gambar 5. Grafik Tentang Unsur Kebersihan Makanan dan Minuman Di Obyek Wisata

Selain itu data $68 \%$ responden mengatakan bahwa makanan dan minuman yang ditawarkan di obyek wisata sudah bersih sehingga tidak khawatir untuk mengkonsumsinya dan hanya $4 \%$ yang menyatakan tidak serta $28 \%$ masih menyatakan ragu-ragu terhadap hal tersebut karena pedagang menjual makanan dan minuman di pinggir jalan sehingga masih memungkinkan terkena debu.

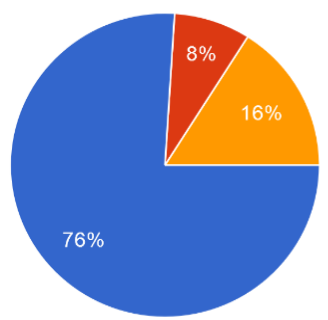

$$
\begin{aligned}
& \text { Ya } \\
& \text { Tidak } \\
& \text { Ragu-ragu }
\end{aligned}
$$

Sumber Data Peneliti (2020)

Gambar 6. Grafik Tentang Tempat Sampah Yang Bersih Di Obyek Wisata

Hal yang paling penting dalam unsur kebersihaan adalah fasilitas tempat sampah yang ada di obyek wisata sudah bersih sehingga pengunjung nyaman menggunakannya itu menurut pendapat $76 \%$ responden dan $8 \%$ merasa tidak serta $16 \%$ masih mengatakan ragu-ragu karena responden merasa kesulitan mencari tempat sampah.
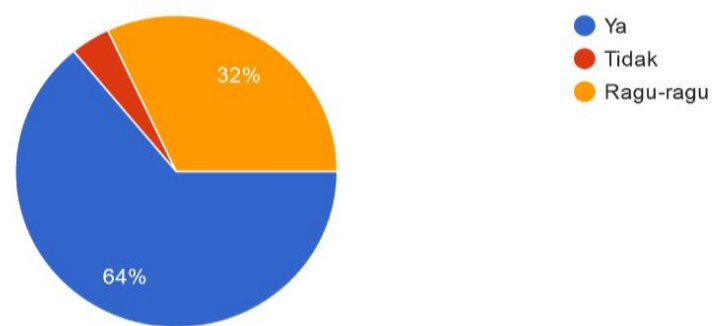

Sumber Data Peneliti (2020)
Gambar 6. Grafik Tentang Fasilitas Toilet Yang Bersih Di Obyek Wisata

Persoalan fasilitas di obyek wisata tentu bermacam-macam ada yang bersih ada yang kotor atau jorok. Menurut pendapat pengunjung yang berkunjung di obyek wisata Candi ljo bahwa kamar mandi/toilet dalam keadaan bersih sehingga nyaman menggunakannya hal ini menurut oleh $64 \%$ pengunjung dan $4 \%$ menyatakan tidak serta $32 \%$ masih mengatakan ragu-ragu terhadap hal tersebut karena pengunjung tidak menggunakan fasilitas toilet. Dalam hal penggunaan pakaian yang bersih dan rapi menurut $84 \%$ menyatakan sudah bersih dan rapi dan hanya $16 \%$ menyatakan ragu-ragu dalam pernyataan tersebut karena pengunjung tidak begitu memperhatikan.

\section{Sejuk}

Suasana dalam obyek wisata yang diinginkan oleh wisatawan adalah sejuk dan nyaman. Pada obyek wisata ini dalam penataan pepohonan sudah bagus sehingga menciptakan suasana di obyek wisata di Candi ljo yang sejuk hal itu dikatakan oleh 96\% pengunjung dan 4\% mengatakan masih menyatakan ragu-ragu karena pengunjung merasa panas
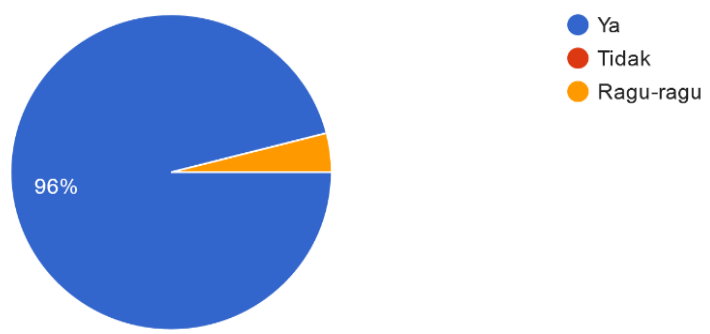

Sumber Data Peneliti (2020)

Gambar 7. Grafik Tentang Suasana Sejuk Di Obyek Wisata

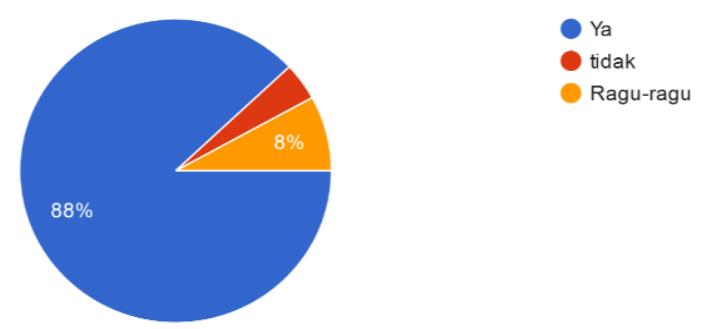

Sumber Data Peneliti (2020)

Gambar 8. Grafik Tentang Lingkungan Yang Asri Di Obyek Wisata

Dalam hal penataan lingkungannya asri sehingga membuat udara sejuk, seperti sirkulasi udara yang baik, Penataan tanaman 
yang indah membuat pengunjung Candi ljo merasa nyaman dengan kesejukan di dalam objek wisata ini sesuai dengan pernyataan $88 \%$ pengunjung dan $8 \%$ mengatakan masih ragu-ragu karena cuaca panas.

\section{Unsur Indah}

Daya tarik wisata salah satunya adalah keindahaan untuk itu dalam penelitian ini bahwa wisata Candi ljo mempunyai pemandangan alam yang menarik hal ini dikatakan oleh $92 \%$ responden yang berkunjung kesana dan hanya $8 \%$ yang mengatakan masih ragu-ragu karena sampai di Candi ljo sudah gelap sehingga keindahan alamnya tidak begitu terlihat. Selain itu dalam keaslian atraksi alam yang indah seperti pemandangan alam yang ditawarkan di obyek wisata Candi ljo Prambanan bahwa 92\% menyetujui dan 8\% menyatakan masih ragu-ragu karena pada waktu berkunjung masih dalam tahap pengembangan.
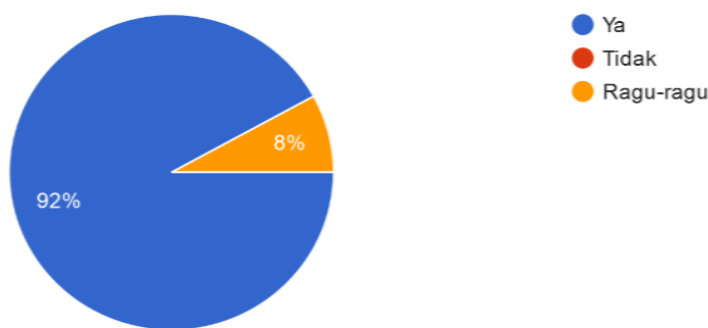

Sumber Data Peneliti (2020)

Gambar 9. Grafik Tentang Pemandangan Yang Menarik Di Obyek Wisata

Untuk tatanan yang alami dan harmoni dengan memperhatikan alam sekitar juga di nilai baik hal ini menurut $84 \%$ pengunjung yang berwisata di obyek wisata tersebut dan hanya $16 \%$ menyatakan masih ragu-ragu karena takut pada ketinggian.

\section{Unsur Ramah}

Wisatawan saat datang ke obyek wisata harapannya adalah keramah tamahan yang ingin didapat dan dalam hal aspek ramah tamah didapat kuesioner yang menaggapi bahwa 96\% merasa bahwa mereka mendapatkan pelayanan yang sangat ramah sehingga tidak merasa cemas berada di objek wisata ini dan $4 \%$ mengatakan masih ragu-ragu karena merasa kurang mendapatkan keramahan. Data yang lain adalah $96 \%$ pengunjung merasa nyaman dengan keramah-tamahan masyarakat sekitar obyek wisata ini dan hanya $4 \%$ yang menjawab ragu-ragu karena merasa kurang mendapatkan keramahan dari masyarakat.

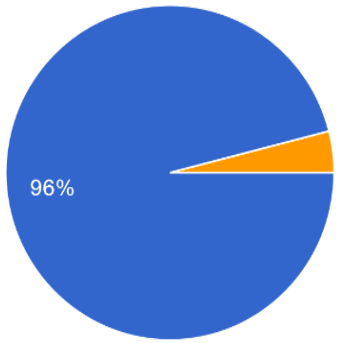

Ya

Tidak

Ragu-ragu
Sumber Data Peneliti (2020)

Gambar 10. Grafik Tentang Pelayanan Yang Ramah Di Obyek Wisata

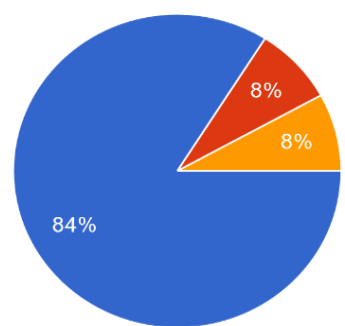

$$
\begin{aligned}
& \text { Ya } \\
& \text { Tidak } \\
& \text { Ragu-ragu }
\end{aligned}
$$

Sumber Data Peneliti (2020)

Gambar 11. Grafik Tentang Petugas Informasi Yang Ramah Di Obyek Wisata

Unsur dalam keramah tamahaan adalah tentang tanggapan terhadap masyarakat dan petugas informasi yang ramah memberikan informasi sehingga mereka tidak merasa canggung merupakan pernyataan dari data $84 \%$ dan $8 \%$ responden mengatakan tidak dan hanya $8 \%$ saja yang mengatakan ragu-ragu karena tidak melihat pemandunya.

\section{Unsur Kenangan}

Unsur Sapta Pesona yang ketujuh yaitu Kenangan yang didapat setelah berkunjung ke suatu obyek wisata dan untuk para wisatawan yang telah berkunjung ke obyek wisata Candi ljo menyatakan bahwa $88 \%$ terkesan dengan keindahan alam di obyek wisata ini dapat memberikan kenangan yang baik bagi mereka dan $4 \%$ mengatakan tidak serta $8 \%$ mengatakan masih ragu-ragu dalam hal tersebut karena takut ketinggian.
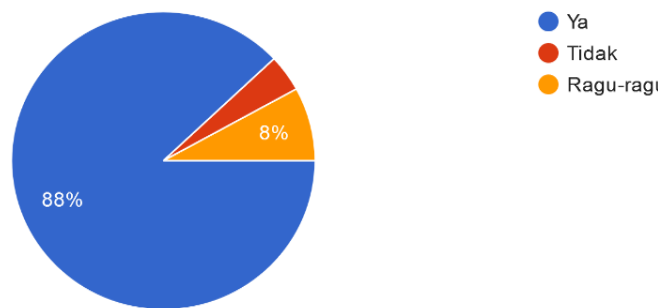

Sumber Data Peneliti (2020)

Gambar 12. Grafik Tentang Responden Terkesan Keindahaan Di Obyek Wisata 
Selain itu obyek wisata Candi ljo mengangkat budaya lokal sebagai atraksi untuk menarik pengunjung hal ini disampaikan $100 \%$ pengunjung wisatawan. Kemudian menurut $60 \%$ pengunjung mereka membeli cinderamata/ souvenir khas di dalam objek wisata ini sehingga menjadi souvenir yang akan dibawa pulang dan $20 \%$ menyatakan tidak membeli cinderamata/souvenir untuk oleh saat dibawa pulang serta $20 \%$ menyatakan ragu-ragu karena pedagang yang menjual cindera mata masih sedikit sehingga pilihan cinderamata masih sangat sedikit.Terungkap juga bahwa $72 \%$ pengunjung mengatakan bawa obyek wisata sudah menyediakan berbagai macam kuliner lokal yang khas sehingga menjadi cerita pada orang lain yang ingin berkunjung dan $8 \%$ menyatakan tidak menyediakan serta 30\% menyatakan masih ragu-ragu karena bisa mendapatkan kuliner tersebut di tempat lain.
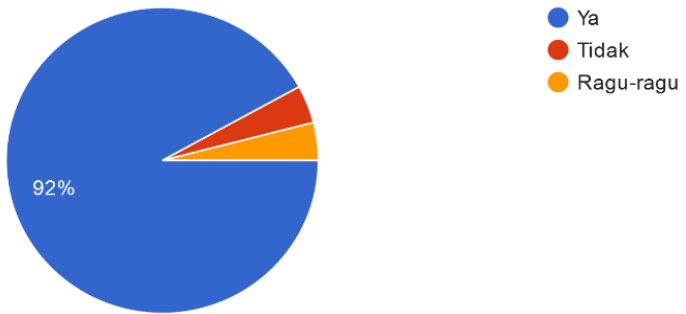

Sumber Data Peneliti (2020)

Gambar 13. Grafik Tentang Responden

Merekomnedasikan Ke Orang Lain Tentang Obyek Wisata Ini

Pada penelitian ini bahwa pengunjung wisata Candi ljo sebesar 92\% akan menceritakan semua apa yang didapat setelah selesai berkunjung dan akan merekomendasikan jika ada yang ingin berkunjung ke obyek wisata di Yogyakarta dan hanya $4 \%$ menyatakan tidak merekomnedasikan ke orang lain agar mau berkunjung ke obyek wisata tersebut dan $4 \%$ menyatakan masih ragu-ragu tentang hal tersebut karena lokasi sangat tinggi dan panas.

Dari uraian diatas tentang persepsi wisatawan tentang Sapta Pesona di candi ljo Prambanana mayoritas responden menyatakan bahwa unsur-unsur Sapta Pesona sudah berjalan dengan baik dalam penerapannya oleh pengelola obyek wisata. Tanggapan responden dapat dilihat dalam table berikut ini:
Tabel 2. Tanggapan Responden Tentang Sapta Pesona

\begin{tabular}{lllll}
\hline $\begin{array}{l}\text { Unsur } \\
\text { sapta } \\
\text { Pesona }\end{array}$ & $\begin{array}{l}\text { Tanggapan } \\
(\%)\end{array}$ & Respoden & Total \\
\hline \multicolumn{5}{l}{ Setuju } \\
\cline { 2 - 5 } & $\begin{array}{l}\text { Ragu- } \\
\text { ragu }\end{array}$ & $\begin{array}{l}\text { Tidak } \\
\text { Setuju }\end{array}$ \\
\hline Aman & $88 \%$ & $12 \%$ & - & $100 \%$ \\
\hline Bertib & $80 \%$ & $12 \%$ & $8 \%$ & $100 \%$ \\
\hline Sejuk & $80 \%$ & $20 \%$ & - & $100 \%$ \\
\hline Indah & $96 \%$ & $4 \%$ & - & $100 \%$ \\
\hline Ramah & $92 \%$ & $8 \%$ & - & $100 \%$ \\
\hline Kenangan & $88 \%$ & $4 \%$ & - & $100 \%$ \\
\hline Sumber Data & $88 \%$ & $4 \%$ & $100 \%$ \\
\hline
\end{tabular}

Sumber Data Peneliti (2020)

Di saat ini menghadapi wabah pandemi covid-19 bahwa program Sapta Pesona sangat dibutuhkan oleh pengelola obyek wisata karena didalam unsur-unsur program tersebut ada perlindungan dan pencegahaan penularan penyakit tersebut jadi program masih sangat relevan dalam kondisi pandemi sekarang ini.

Obyek wisata Candi ljo sebagai wisata pendidikan dan sejarah serta budaya sebelum pandemi selalu ramai dikunjungi wisatawan karena berada di atas bukit dengan pemandangan yang menarik tentu perlu pengelolaan yang serius oleh pengelola untuk itu program Sapta Pesona merupakan sarana untuk menarik pengunjung agar selalu menjadi favorit bagi para wisatawan. Dengan program Sapta Pesona yang dilaksanakan dengan baik tentu kedepannya obyek wisata akan selalu ramai dikunjungi.

\section{PENUTUP}

Berdasarkan hasil penelitian dapat disimpulkan bahwa persepsi wisatawan terhadap Sapta Pesona di obyek wisata Candi ljo di nilai sudah baik hal ini dari data pernyataan responden yang menyatakan bahwa unsur keamanan sudah berjalan baik, $88 \%$ responden menyatakan setuju, $12 \%$ menyatakan ragu-ragu. Ketertiban dalam saat menggunakan sarana dan prasarana Objek Wisata juga baik, $80 \%$ responden menyatakan setuju, $12 \%$ ragu-ragu dan $8 \%$ tidak setuju. Kebersihan lingkungan obyek wisata juga dalam keadaan bersih, $80 \%$ responden menyatakan setuju, dan $20 \%$ ragu-ragu. Penataan tanaman yang indah membuat pengunjung merasa nyaman dengan kesejukan di dalam Objek Wisata, sebanyak $96 \%$ responden menyatakan setuju dan hanya $4 \%$ yang merasa ragu-ragu. Data responden 
menyetujui bahwa unsur keindahaan sudah sesuai dengan lingkungan sekitar obyek wisata ini ditata dengan teratur sehinga nyaman untuk di lihat pengunjung, 92\% responden setuju dan $8 \%$ ragu-ragu.. Dalam hal masalah keramah tamahaan 96 responden merasa mereka mendapatkan pelayanan yang sangat ramah baik dari masyarakat dan petugas sehingga tidak merasa cemas berada di objek wisata, dan $4 \%$ ragu ragu. Sedangkan untuk unsur kenangan bahwa $88 \%$ responden terkesan dengan keindahan alam di obyek wisata ini dapat memberikan kenangan yang baik dan akan merekomendasikan ke orang lain untuk berkunjung ke obyek wisata Candi ljo di Prambanan Sleman Yogyakarta, $8 \%$ ragu-ragu dan $4 \%$ tidak setuju.

Dalam penelitian ini penulis mengalami kendala karena adanya wabah Covid -19 yang membuat pengambilan data terhadap pengunjung kurang maksimal karena penulis tidak dapat bertemu secara langsung dengan responden. Berdasarkan kesimpulan yang diuraikan, maka penulis dapat menyampaikan beberapa saran dalam masalah program Sapta Pesona dimana dalamnya ada unsur-unsur yang dapat membantu pengelola obyek wisata Candi ljo antara lain dalam pengembanagan obyek wisata tetap mempertahankan himbauan-himbauan yang ada di program Sapta Pesona yaitu menjaga keamanan, kebersihan, ketertiban, keindahaan, kesejukkan, kenyaman dan kenangan sehingga dapat meningkatkan kunjungan wisatawan. Pada saat wabah pandemi Covid-19 yang melanda dunia perlu ditingkatkan program Sapta Pesona untuk diterapkan sehingga wisatawan akan terjamin keamanan dan kesehatan saat berkunjung ke obyek wisata ini.

\section{DAFTAR PUSTAKA}

Atmoko, Prasetyo Hadi. 2014. Strategi Pengembangan Potensi Desa Wisata Brajan Kabupaten Sleman. Jurnal Media Wisata Vol 12 No 2 (2014), STP AMPTA.

Azwar S. 2013. Sikap Manusia: Teori dan Pengukurannya. Yogyakarta: PustakaPelajar

Fandeli, Chafid, 2001. Dasar-dasar Manajemen Kepariwisataan Alam. Liberty Offset: Yogyakarta.

Moleong, Lexy J.2010. Metodologi Penelitian Kualitatif. Bandung: Remaja Rosdakarya.

Notoatmodjo, Soekidjo. 2012. Pendidikan dan perilaku kesehatan. Jakarta: Rineka Cipta.

Peraturan Pemerintan Tahun 1990. UndangUndang Republik Indonesia No 9 Tahun 1990 Tentang Kepariwisataan. Sekretariat Negara. Jakarta

Ramadhani, Yosi (2015) Pengaruh Persepsi Mahasiswa Tentang Profesi Guru Dan Minat Menjadi Guru Terhadap Indeks Prestasi Mahasiswa Semester Enam Prodi Administrasi Perkantoran Fakultas Ekonomi Unimed

Rajesh, R. 2013.Impact Of Tourist PerCeptions, Destination Image Andtourist Satisfaction On Destinationloyalty:A Conceptual Model. Pa-sos, vol.11: 67-78.

Satria, D. 2009. Strategi pengembangan ekowisata berbasis ekonomi local dalam rangka program pengenta-san kemiskinan di wilayah Kabupaten Malang. Journal of Indone-sian Applied Economics, vol3:37-47.

Walgito, Bimo. 2010. Pengantar Psikologi Umum. Yogyakarta: C.V Andi. 